Creative Commons User License: CC BY-NC-ND

Abstracted by: EBSCOhost, Electronic Journals Service (EJS),

Google Scholar, Journal Seek, Scientific Commons,

Food and Agricultural Organization (FAO), CABI and Scopus
Journal of Agricultural Extension

Vol. 23 (1) January, 2019

ISSN(e): 24086851; ISSN(Print); 1119944X

http://journal.aesonnigeria.org

http://www.ajol.info/index.php/iae

Email: editorinchief@aesonnigeria.org

\title{
Implications of Empowerment Status in Agricultural Production Capabilities of Rural Women in Selected States of Nigeria
}

https://dx.doi.org/10.4314/jae.v23i1.4

\section{Adeleke Oluwaseun. A.}

Department of Agricultural Extension and Rural Development, University of Ibadan, Nigeria

Email: aladeoluwaseun@yahoo.com,

Phone: +2348038079312

Akinbile Luqman. A.

Department of Agricultural Extension and Rural Development, University of Ibadan, Nigeria Email:: lakinbile@yahoo.com

Phone: +2348023250454

\section{Abstract}

This study assessed the implications of empowerment status in agricultural production capabilities of rural women in selected states of Nigeria using five main indicators of empowerment; decision-making status, economic status, social status, political status and time-use status. Multi-stage sampling technique was used to randomly select four States (Oyo, Edo, Benue and Sokoto States) from the six agricultural zones in Nigeria. From each state, $10 \%$ of the rural Local Government Areas (LGAs) were purposively selected making a total of nine LGAs. Two communities were randomly selected from each LGA to give 18 rural communities. Rural women were systematically sampled proportionate to the size of each community to give 261 respondents. Data were analysed using descriptive statistics, PPMC and ANOVA. Respondents had low decision-making status ( $\bar{x}=32.4)$, high economic status $(\bar{x}=83.1)$, high social status $(\bar{x}=7.6)$, low political status $(\bar{x}=11.7)$ and high time-use $(\bar{x}=20.7)$ status and a low empowerment status $(\bar{x}=155.5)$ across States. Result shows that there was a significant difference $(F=47.615)$ in the empowerment status of respondents across selected states. Income ( $r=0.403)$, educational attainment ( $r=0.478)$, household size $(r=0.084)$ and years of experience $(r=0.235)$ had significant positive relationship with empowerment status. Rural women should be empowered by government agencies and NGOs through organising seminars on self-help projects and giving them voice which will enable them to have a sustainable farm enterprise.

Keywords: Capabilities, economic empowerment, production, rural, status. 
Creative Commons User License: CC BY-NC-ND

Abstracted by: EBSCOhost, Electronic Journals Service (EJS),

Google Scholar, Journal Seek, Scientific Commons,

Food and Agricultural Organization (FAO), CABI and Scopus

http://eoi.citefactor.org/10.11226/v23i1
Journal of Agricultural Extension

Vol. 23 (1) January, 2019

ISSN(e): 24086851; ISSN(Print); 1119944X

http://journal.aesonnigeria.org

http://www.ajol.info/index.php/jae

Email: editorinchief@aesonnigeria.org

\section{Introduction}

Rural women across the globe possess great potentials for increasing agricultural productivity and development of any nation. Doss (2017) affirmed that empowering women through availability of productive resources is key to increasing overall agricultural productivity, improving women wellbeing and reducing poverty. Empowering rural women has been found to significantly impact the livelihood of households, communities and the nation at large (Ogato, 2013). However, women are often not empowered with basic productive resources that will contribute to high agricultural productivity.

Empowerment has been defined as the expansion of assets and capabilities of poor people to participate in, negotiate with, influence, control and hold accountable institutions that affect their lives (Narayan, 2005). Empowerment is not a onetime event but a process that its outcome will be favourable to the livelihood, well-being and standard of living of rural women. Empowerment will also increase women access to resources because it is believed that empowering women would reduce the incidence of poverty, increase employment opportunities and household income which will eventually lead to sustainable economic development (Adeleke, Adeoye and Odedeji, 2016). Also, improving the wellbeing of rural women and offering them several opportunities will give them the potential to create positive impact on the next generation (Diiro, Seymour, Kassie, Muricho and Muriithi, 2018). It is unfortunate that rural women are at disadvantaged position especially in the aspect of being empowered for agricultural production. This is due to lack of access to lands, credits and other basic inputs that will help to increase their efforts and maximise their potentials in production.

There is expectation that food demand will increase by $59 \%$ to $98 \%$ by the year 2050 due to increase in population and challenges faced in the agricultural sector like climate change and urbanisation (Elferink and Schierhorn, 2016). To solve this challenge, farmers will need to increase food production either by expanding agricultural lands to grow crops on or introduce other practices like irrigation and precision farming. Also, the empowerment of small holder farmers in which rural women form the majority must be given significant attention by supplying basic resources that will boost agricultural production. Furthermore, their ability to participate in making decisions both at the household and community level will contribute to high efficiency and increase their capabilities to work effectively.

Women capability is one of the main objectives of human resource development which is aimed at heightening women's knowledge, awareness, confidence and freedom (Sadeghi, Arezoumandan and Nejati, 2015). Rural women will be able to achieve livelihood capabilities when they are empowered because they will be able to cope with stress and shocks. However, most women in rural communities of Nigeria are left in various states of lack, poverty and inability to cope with various challenges they encounter in their daily lives. Karim, Lindberg and Wamala (2017) affirmed that rural women lack access to basic assets and social rights due to patriarchal nature of some communities which hinders their full participation in agricultural production and developmental process. Most often, they are left in a state of being disempowered and are not able to take responsibilities on issues that are pertinent to them which necessitated this study to be conducted in various rural communities of Nigeria. 
Creative Commons User License: CC BY-NC-ND

Abstracted by: EBSCOhost, Electronic Journals Service (EJS),

Google Scholar, Journal Seek, Scientific Commons,

Food and Agricultural Organization (FAO), CABI and Scopus

http://eoi.citefactor.org/10.11226/v23i1
Journal of Agricultural Extension

Vol. 23 (1) January, 2019

ISSN(e): 24086851; ISSN(Print); 1119944X

http://journal.aesonnigeria.org

http://www.ajol.info/index.php/jae

Email: editorinchief@aesonnigeria.org

\section{Objectives of the study}

The general objective of the study was to assess the implications of empowerment status in agricultural production of rural women in selected States of Nigeria. The specific objectives were to:

- describe the socio-economic characteristics of rural women in the area;

- identify the farming characteristics of rural women in the area and

- ascertain the empowerment status of rural women using five main indicators; decision-making status, economic status, social status, political status and time-use status.

\section{Hypotheses}

$\mathrm{H}_{01}$ : There is no significant difference in the empowerment status of rural women across selected states in Nigeria.

$\mathrm{H}_{02:}$ There is no significant relationship between the socio-economic/farming characteristics of respondents and their empowerment status

\section{Methodology}

The study was carried out in Oyo, Benue, Edo and Sokoto States.

It is located between latitudes $8.1^{\circ} \mathrm{N}$ and longitudes $3 \cdot 4^{\circ} \mathrm{E}$. It covers a total landmass of 28 , $454 \mathrm{~km}^{2}$. The State presently has 33 Local Government Areas. The Oyo State Agricultural Development Programme (OYSADEP) has its headquarters in Saki and the agricultural zone is divided into four, namely: Oyo, Saki, Ogbomoso and lbadan/lbarapa.

Benue State is located between latitude $7.3^{\circ} \mathrm{N}$ and longitude $8.8^{\circ} \mathrm{E}$ and has a landmass area of $34,059 \mathrm{sqkm}$ and a total population of $5,181,642$. The State has 23 Local Government Areas. The major occupation in the State is farming. The State has three agricultural zones namely: A, B and C which are Northern, Eastern and Central zones, respectively.

Edo State has a total land area of $17,802 \mathrm{~km}^{2}$ and population of $3,497,502$. It lies geographically on latitude $6.5^{\circ} \mathrm{N}$ and longitude $5.9^{\circ} \mathrm{E}$. Edo State has 18 Local Government Areas. The State has three agricultural zones namely: Edo north, Edo south and Edo central.

Sokoto State occupies $25,973 \mathrm{sqkm}$. It lies geographically latitude $12.9^{\circ} \mathrm{E}$ and longitude $5.2^{0}$ $\mathrm{N}$. The State has 23 Local Government Areas and two agricultural zones, Northern and Southern zone.

A multi-stage sampling procedure was used to select respondents for this study. In the first stage, four out of the six agricultural zones in the country were randomly selected which are South-west, South-south, North-central and North-west. In the second stage, one state was randomly selected from each of the zones and they were Oyo, Edo, Benue, and Sokoto, respectively. In the third stage, ten percent of rural local government areas (LGAs) were purposively selected from each state making 3 from Oyo, 2 from Edo, 2 from Benue, and 2 from Sokoto states making a total of nine (9) LGAs. ATISBO, Saki east and Kajola LGAs were selected from Oyo, Etsako west and Owan east LGAs were selected from Edo, Gboko and Tarka LGAs were selected from Benue while Wurno and Rabah LGAs were selected from Sokoto State. Two communities were randomly selected from each LGA making a total of eighteen (18) rural communities from all the LGAs. Random sampling was used to select fifteen rural women from each community making a total of 270 women that formed the 
Creative Commons User License: CC BY-NC-ND

Abstracted by: EBSCOhost, Electronic Journals Service (EJS),

Google Scholar, Journal Seek, Scientific Commons,

Food and Agricultural Organization (FAO), CABI and Scopus

http://eoi.citefactor.org/10.11226/v23i1
Journal of Agricultural Extension

Vol. 23 (1) January, 2019

ISSN(e): 24086851; ISSN(Print); 1119944X

http://journal.aesonnigeria.org

http://www.ajol.info/index.php/jae

Email: editorinchief@aesonnigeria.org

sample size for the study out of which 261 was eventually used for the analysis and presentation of results.

The empowerment status of respondents was measured by pooling the scores of each of the empowerment indicators (decision making status, economic status, social status, political status and time use status) together and they were standardised.

Decision making status was operationalised by asking respondents to indicate who make decisions on productive and domestic issues ( 7 items each) which were measured on a four point Likert type-scale of sole decision (3), joint decision (2), husband decision (1) and no decision (0). Mean score of 32.4 was obtained which was used to categorise the respondents into those having high and low decision making status.

Economic status was operationalised by using three components: ownership of assets, control of assets and access to credits. Respondents were to indicate if they own certain items (17 items) and have control over them which was measured on a four point Likert type-scale of personal (3), joint (2), husband (1) and no ownership (0). Control over assets was measured using have control (1) and no control (0). Access to credits was operationalised by asking respondents if they had access to credits like cooperatives, esusu, contributions, microfinance bank, etc which was measured as high (2), low (1) and no access (0). Scores of access to credits, ownership and control of assets were pooled together and standardised to form the economic status. Maximum score of 112.0 and minimum score of 51.0 was generated. Mean score of 83.1 was also generated which was used to categorise the respondents into those having high and low economic status.

Respondents were asked to indicate if they belonged to social groups (6 groups) with response options of 'Yes' or 'No' which was used to determine their social status.

Political status was operationalised by asking the respondents to indicate their leadership position in the group which was measured with response options of 'Yes' or 'No'.

Time-use status was operationalised by asking the respondents to indicate if they were satisfied with time used for certain activities (11 activities) which were operationalised on a three point Likert type-scale of very satisfied (2), satisfied (1) and not satisfied 0 ). Mean score of 20.7 was obtained which was used to categorise the respondents into those having high and low time-use status.

\section{Results and Discussion}

Table 1 indicates that the overall mean age of the respondents is $29 \pm 5.3$ years. Results show that $66.7 \%$ of the respondents are within the age range of 21 -30years which implies that the women were in their reproductive and productive years. Acharya, Bell, Simkhada, Teijlingen and Regmi (2010) affirmed that women's age is a strong determinant in making family decisions which tends to improve their status and self-worth. The educational attainment of respondents reveals that greater proportion $(43.7 \%)$ of the respondents had no formal education, $32.6 \%$ had primary education with $16.9 \%$ having secondary education. This suggests that the educational status of respondents is low and this may likely affect their empowerment status. Fabiyi and Akande (2015) reported that women in most rural areas of Nigeria are less educated. Also, the mean annual income of respondents is \#70,937 $\pm 67,033$. This supports the findings of Akinbode and Hamzat (2017) that the majority of rural women earned $\$ 70,200$ annually which is very low compared to poverty line of $\$ 1.90$ per day ( $\$ 259,200$ per annum) recommended by World Bank in 2015 . This suggests that respondents are less financially empowered. The study also revealed that 
Creative Commons User License: CC BY-NC-ND

Abstracted by: EBSCOhost, Electronic Journals Service (EJS),

Google Scholar, Journal Seek, Scientific Commons,

Food and Agricultural Organization (FAO), CABI and Scopus

http://eoi.citefactor.org/10.11226/v23i1
Journal of Agricultural Extension

Vol. 23 (1) January, 2019

ISSN(e): 24086851; ISSN(Print); 1119944X

http://journal.aesonnigeria.org

http://www.ajol.info/index.php/iae

Email: editorinchief@aesonnigeria.org

$39.8 \%$ of the respondents were into crop farming, $19.2 \%$ involved in trading with the majority $(69.9 \%)$ of them engaging in small scale business and $15.7 \%$ as artisans which implies that rural women were involved in various livelihood activities which is expected to boost their financial status and help them meet family needs.

Table 1: Socio-economic characteristics

\begin{tabular}{|c|c|c|c|c|c|}
\hline $\begin{array}{l}\text { Socio-economic } \\
\text { characteristics }\end{array}$ & $\begin{array}{l}\text { Oyo } \\
\text { State } \\
\%\end{array}$ & $\begin{array}{c}\text { Edo State } \\
\%\end{array}$ & $\begin{array}{c}\text { Benue } \\
\text { State } \\
\%\end{array}$ & $\begin{array}{c}\text { Sokoto } \\
\text { State } \\
\% \\
\end{array}$ & $\begin{array}{c}\text { Total } \\
\%\end{array}$ \\
\hline \multicolumn{6}{|l|}{ Age (years) } \\
\hline $16-20$ & 0 & 1.7 & 15.0 & 15.7 & 6.9 \\
\hline $21-25$ & 11.1 & 23.3 & 10.0 & 41.2 & 21.8 \\
\hline $26-30$ & 26.7 & 48.3 & 21.7 & 41.2 & 34.9 \\
\hline $31-35$ & 40.0 & 23.3 & 28.3 & 2.0 & 25.3 \\
\hline $36-40$ & 22.2 & 3.3 & 25.0 & 0 & 11.1 \\
\hline Mean & 31 & 29 & 28 & 32 & 29 \\
\hline SD & \pm 4.5 & \pm 4.1 & \pm 6.1 & \pm 4.5 & \pm 5.3 \\
\hline \multicolumn{6}{|l|}{ Educational attainment } \\
\hline No formal education & 33.3 & 40.0 & 45.0 & 64.7 & 43.7 \\
\hline Primary education & 44.4 & 33.3 & 25.0 & 19. 6 & 32.6 \\
\hline Secondary education & 12.2 & 25.00 & 25.0 & 5.8 & 16.9 \\
\hline Tertiary education & 2.2 & 0 & 5.0 & 0 & 1.9 \\
\hline Adult literacy education & 7.8 & 0 & 0 & 0 & 2.7 \\
\hline Koranic education & 0 & 1.7 & 0 & 9.8 & 2.3 \\
\hline \multicolumn{6}{|l|}{ 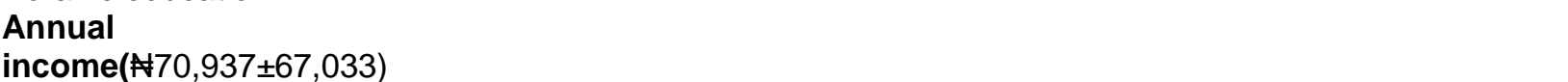 } \\
\hline $0-67,000$ & 31.1 & 76.7 & 90.0 & 90.2 & 66.7 \\
\hline $67001-134,000$ & 52.2 & 23.3 & 1.7 & 9.8 & 25.7 \\
\hline $134,001-201,000$ & 16.7 & 0 & 8.3 & 0 & 7.6 \\
\hline \multicolumn{6}{|l|}{ Household size } \\
\hline $1-4$ & 18.9 & 16.7 & 26.7 & 17.6 & 19.9 \\
\hline $5-8$ & 81.1 & 78.3 & 61.7 & 76.5 & 75.1 \\
\hline $9-12$ & 0 & 5.0 & 11.6 & 5.9 & 5.0 \\
\hline Mean, SD & $6 \pm 1.8$ & & & & \\
\hline \multicolumn{3}{|l|}{ Primary occupation } & & 17.6 & 39.8 \\
\hline Food crop farming & 12.2 & 8.3 & 0 & 42.1 & 14.6 \\
\hline Processing & 24.4 & 16.7 & 8.3 & 7.8 & 15.7 \\
\hline Artisans & 31.1 & 18.3 & 11.7 & 7.8 & 19.2 \\
\hline $\begin{array}{l}\text { Trading } \\
\text { Full housewife }\end{array}$ & 4.4 & 11.7 & 8.4 & 23.5 & 10.7 \\
\hline \multicolumn{6}{|l|}{$\begin{array}{l}\text { Full housewite } \\
\text { Scale of business }\end{array}$} \\
\hline Small & 60.0 & $\begin{array}{l}72.2 \\
278\end{array}$ & 78.9 & 100.0 & 69.9 \\
\hline Medium & 40.0 & 27.8 & 21.1 & 0 & 30.1 \\
\hline \multicolumn{6}{|l|}{ Husband's educational } \\
\hline attainment & & 15.0 & 5.0 & 9.8 & 6.9 \\
\hline No formal education & 41.2 & 30.0 & 35.0 & 21.6 & 33.3 \\
\hline Primary education & 37.8 & 40.0 & 50.0 & 13.7 & 36.4 \\
\hline Secondary education & 5.6 & 10.0 & 10.0 & 2.0 & 6.9 \\
\hline Tertiary education & 4.4 & 0 & 0 & 0 & 1.5 \\
\hline Adult literacy education & 10.0 & 5.0 & 0 & 52.9 & 14.9 \\
\hline Koranic education & 100.0 & 100.0 & 100.0 & 100.0 & 100.0 \\
\hline
\end{tabular}

Source: Field survey, 2016 
Creative Commons User License: CC BY-NC-ND

Abstracted by: EBSCOhost, Electronic Journals Service (EJS),

Google Scholar, Journal Seek, Scientific Commons,

Food and Agricultural Organization (FAO), CABI and Scopus

http://eoi.citefactor.org/10.11226/v23i1
Journal of Agricultural Extension

Vol. 23 (1) January, 2019

ISSN(e): 24086851; ISSN(Print); 1119944X

http://journal.aesonnigeria.org

http://www.ajol.info/index.php/jae

Email: editorinchief@aesonnigeria.org

\section{Farming characteristics}

It was revealed from Table 2 that respondents were into cultivation of different crops like maize, cassava, yam, cowpea and vegetables. This result is in consonance with the findings of Ogunsumi, Adeyeye and Fato (2017) that most rural women are involved in the cultivation of different crops like cassava, yam, maize and vegetables for household consumption and sale. Also, $57.3 \%$ of the respondents cultivated less than one acre of farmlands. This implies that most of the respondents do not have access to adequate land for their farming activities and this may affect their level of production and income. This corroborates with the findings of Yusuf, Okunmadewa, Adenegan and Oyekale (2010) who noted that rural women have low access to a large area of land for cultivation. Also, 39.1\% and $22.2 \%$ of the respondents use family and hired labour, respectively. This suggests that some respondents make use of their children to meet farming labour needs and some could afford to pay for hired labourers. Few $(11.5 \%)$ of the respondents had access to personal land while $51.3 \%$ of them use family land. This is in tandem with the findings of lyela and Ikwuakam (2015) that rural women do not own land and may have limited access to self-purchased land for farming. Furthermore, table 2 reveals that the mean for the years of experience in various enterprises is $4.6 y e a r s$. Also, $48.3 \%$ of the respondents did not give years of experience in their enterprise probably due to lack of keeping records or inability to recall from memory. This affirms the findings of Dudafa (2013) that rural women do not attach a great deal of importance to record keeping on their farm activities and other aspects of their lives. 
Creative Commons User License: CC BY-NC-ND

Abstracted by: EBSCOhost, Electronic Journals Service (EJS),

Google Scholar, Journal Seek, Scientific Commons,

Food and Agricultural Organization (FAO), CABI and Scopus

http://eoi.citefactor.org/10.11226/v23i1
Journal of Agricultural Extension

Vol. 23 (1) January, 2019

ISSN(e): 24086851; ISSN(Print); 1119944X

http://journal.aesonnigeria.org

http://www.ajol.info/index.php/iae

Email: editorinchief@aesonnigeria.org

Table 2: Distribution of respondents according to their Farming characteristics

$\begin{array}{lccccc}\text { Farming } & \text { Oyo State } & \text { Edo State } & \text { Benue State } & \text { Sokoto State } & \text { Total } \\ \text { characteristics } & \% & \% & \% & \% & \%\end{array}$

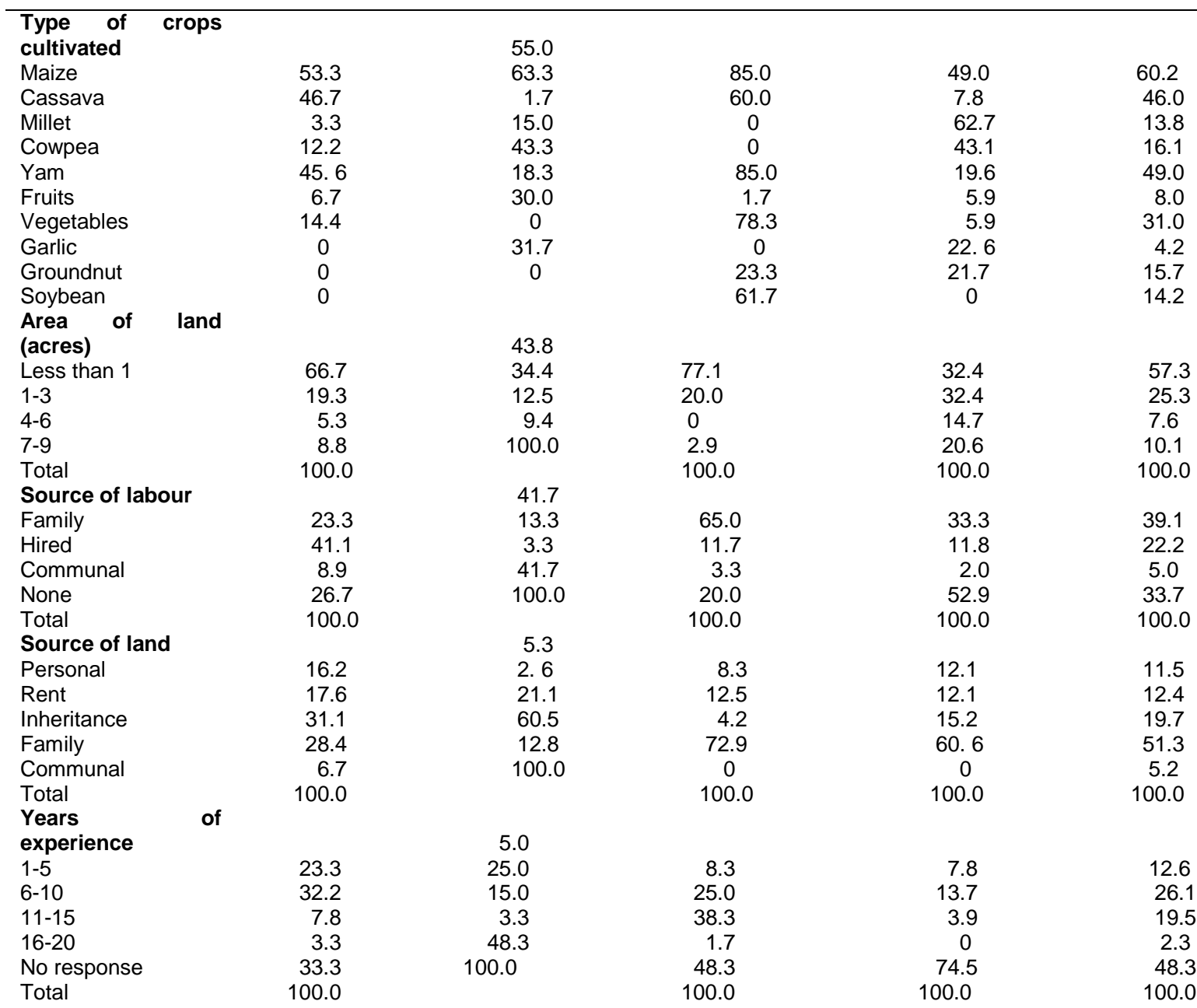

Source: Field survey, 2016

\section{Indicators of Empowerment}

\section{Decision-making status}

Table 3 shows that there is generally low decision-making status among the respondents. This is expected as most of the respondents do not make decisions on most of the productive and family decisions except for few. About $63.6 \%$ and $54.0 \%$ of respondents' husbands made decisions on use of land and inputs to be used on farmland, respectively. Also, $57.9 \%$ and $64.4 \%$ of their husbands made decisions on food to be eaten in the house and use of money, respectively. This suggests that most of the respondents do not make decisions in the family which is due to patrilineal culture that still dominates most part of the rural areas in these states. This finding is supported by Ajadi, Oladele, Ikegami and Tsuruta (2015). Also, their level of income and educational attainment has a key role to play in 
Creative Commons User License: CC BY-NC-ND

Abstracted by: EBSCOhost, Electronic Journals Service (EJS),

Google Scholar, Journal Seek, Scientific Commons,

Food and Agricultural Organization (FAO), CABI and Scopus

http://eoi.citefactor.org/10.11226/v23i1
Journal of Agricultural Extension

Vol. 23 (1) January, 2019

ISSN(e): 24086851; ISSN(Print); 1119944X

http://journal.aesonnigeria.org

http://www.ajol.info/index.php/jae

Email: editorinchief@aesonnigeria.org

decision making in the family as supported by Campbell, Prata and Potts (2012) that making decisions on family issues is a factor of education and income.

Table 3: Distribution of respondents on decision-making status

\begin{tabular}{lcccc}
\hline Productive decisions & Sole $\%$ & $\begin{array}{c}\text { Total } \\
\text { Joint \% }\end{array}$ & Husband \% & No \% \\
\hline Use of land & 2.3 & 20.7 & 63.6 & 13.4 \\
Improvement on land & 2.3 & 24.1 & 58.2 & 15.3 \\
Labour to be used & 2.3 & 25.3 & 55.6 & 16.9 \\
Inputs to be used & 2.3 & 24.9 & 54.0 & 18.8 \\
To buy livestock & 3.4 & 19.9 & 32.6 & 44.1 \\
To sell livestock & 3.4 & 21.5 & 31.4 & 43.7 \\
Use of productive resources & 1.9 & 31.0 & 48.7 & 18.4 \\
Family decisions & & & & \\
School children will attend & 0.8 & 48.7 & 49.8 & 0.8 \\
Number of children to be born & 1.9 & 42.9 & 47.1 & 8.0 \\
in the family & & & & \\
Food to be eaten in the house & 7.3 & 34.9 & 57.9 & 0 \\
Visiting clinics when & 18.8 & 47.1 & 34.1 & 0 \\
necessary & 13.0 & 42.5 & 42.1 & 2.3 \\
Use of family planning & 2.7 & 31.8 & 64.4 & 1.1 \\
services & 22.6 & 37.5 & 38.7 & \\
Use of money in the family & & & & \\
Purchase of new items in the & & & & \\
family & & & & \\
\hline Source: Field survey, & & & &
\end{tabular}

Source: Field survey, 2016 
Creative Commons User License: CC BY-NC-ND Abstracted by: EBSCOhost, Electronic Journals Service (EJS), Google Scholar, Journal Seek, Scientific Commons, Food and Agricultural Organization (FAO), CABI and Scopus

http://eoi.citefactor.org/10.11226/v23i1
Journal of Agricultural Extension

Vol. 23 (1) January, 2019

ISSN(e): 24086851; ISSN(Print); 1119944X

http://journal.aesonnigeria.org

http://www.ajol.info/index.php/iae

Email: editorinchief@aesonnigeria.org

\section{Economic status}

Table 4 reveals that $65.5 \%, 63.9 \%$ and $63.2 \%$ of respondents owned cell phones, cooking stove and charcoal pot, respectively probably because they are for their personal use. Husbands of respondents owned land, farm equipments, farm structures and radio. This implies that husbands of respondents own assets that are more valuable in terms of money and value. This is in line with the findings of Tefera (2013) that men still own most valuable assets in most rural areas of developing countries especially land and farm structures.

From table 5, respondents also had control over assets they own. This suggests that ability to control assets is a function of ownership of such asset. This is in agreement with the report of Fletscher and Kenney (2011) that women are less likely to control land, farm structures and large animals such as cows and horses. Furthermore, table 6 shows that $74.3 \%$ of the respondents had access to contributions as a source of credit. Most of the respondents do not have access to loans or microfinance banks. This result implies that respondents may not be able to meet up with their financial responsibilities as they do not have access to credits from seemingly reliable sources due to inability to present collateral in these financial institutions as corroborated by Ojo, Bila and Iheanacho (2015). Also, the high economic status of respondents on table 7 could be attributed to the ability of respondents to own few assets.

\section{Table 4: Ownership of assets}

\begin{tabular}{lcccc}
\hline Assets & Personal (\%) & $\begin{array}{c}\text { Total } \\
\text { Joint (\%) }\end{array}$ & Husband (\%) & No (\%) \\
\hline Land & 1.9 & 20.3 & 66.3 & 11.5 \\
Cattle & 0.8 & 2.3 & 8.0 & 55.6 \\
Sheep & 1.5 & 4.2 & 9.2 & 85.1 \\
Goat & 7.7 & 15.3 & 9.2 & 67.8 \\
Chickens & 7.7 & 6.5 & 14.9 & 60.9 \\
Farm equipment & 1.9 & 15.7 & 60.5 & 20.7 \\
Farm structures & 1.1 & 20.7 & 60.9 & 17.2 \\
Radio & 1.9 & 33.3 & 57.1 & 7.7 \\
Television & 11.9 & 20.3 & 46.7 & 21.1 \\
Cell phone & 65.5 & 9.6 & 11.1 & 13.8 \\
Bicycle & 7.3 & 22.9 & 22.6 & 47.1 \\
Motorcycle & 3.1 & 22.6 & 29.9 & 44.4 \\
Car & 2.3 & 12.3 & 14.2 & 67.4 \\
Chairs & 23.4 & 42.5 & 31.4 & 2.7 \\
Tables & 24.5 & 41.7 & 28.7 & 4.9 \\
Cooking stove & 63.9 & 26.1 & 3.1 & 6.9 \\
Charcoal pot & 63.2 & 26.8 & 3.1 & 6.9
\end{tabular}

\section{Source: Field survey, 2016}


Creative Commons User License: CC BY-NC-ND Abstracted by: EBSCOhost, Electronic Journals Service (EJS), Google Scholar, Journal Seek, Scientific Commons, Food and Agricultural Organization (FAO), CABI and Scopus

http://eoi.citefactor.org/10.11226/v23i1
Journal of Agricultural Extension

Vol. 23 (1) January, 2019

ISSN(e): 24086851; ISSN(Print); 1119944X

http://journal.aesonnigeria.org

http://www.ajol.info/index.php/jae

Email: editorinchief@aesonnigeria.org

\section{Table 5: Control over assets}

\begin{tabular}{lcc}
\hline Hssets & Total & \\
Land & 35.2 & No control (\%) \\
Cattle & 8.4 & 64.8 \\
Sheep & 11.5 & 91.6 \\
Goat & 30.7 & 88.5 \\
Chickens & 21.5 & 69.3 \\
Farm equipment & 57.1 & 64.8 \\
Farm structures & 59.0 & 42.9 \\
Radio & 13.0 & 41.0 \\
Television & 29.5 & 87.0 \\
Cell phone & 93.1 & 70.5 \\
Bicycle & 47.1 & 6.9 \\
Motorcycle & 47.1 & 52.9 \\
Car & 24.9 & 52.9 \\
Chairs & 50.2 & 75.1 \\
Tables & 88.9 & 49.8 \\
Cooking stove & 93.1 & 11.1 \\
Charcoal pot & 93.1 & 6.9 \\
\hline
\end{tabular}

Source: Field survey, 2016

Table 6: Access to credits

Credits

$\begin{array}{ll}\text { Thigh } & \text { Lotal } \\ \text { access } & \text { (\%) }\end{array}$

(\%)

\begin{tabular}{lrrl}
\hline Esusu & 13.4 & 8.0 & 78.5 \\
Cooperative & 12.3 & 7.3 & 80.5 \\
Loan & 7.7 & 11.5 & 80.8 \\
Contribution & 74.3 & 14.6 & 11.1 \\
Friends/relatives & 37.2 & 31.0 & 31.8 \\
Microfinance banks & 3.8 & 12.6 & 85.5 \\
Individual help & 51.3 & 29.1 & 19.5 \\
\hline
\end{tabular}

Source: Field survey, 2016 
Creative Commons User License: CC BY-NC-ND

Abstracted by: EBSCOhost, Electronic Journals Service (EJS),

Google Scholar, Journal Seek, Scientific Commons,

Food and Agricultural Organization (FAO), CABI and Scopus

http://eoi.citefactor.org/10.11226/v23i1
Journal of Agricultural Extension

Vol. 23 (1) January, 2019

ISSN(e): 24086851; ISSN(Print); 1119944X

http://journal.aesonnigeria.org

http://www.ajol.info/index.php/jae

Email: editorinchief@aesonnigeria.org

Table 7: Categorisation of respondents into high and low economic status

\begin{tabular}{llll}
\hline Economic status & $\%$ & Scores & Mean \\
\hline Low & 49.4 & $51.0-83.1$ & 83.1 \\
High & 50.6 & $83.2-112.0$ & \\
\hline
\end{tabular}

\section{Social status}

From Table $8,48.7 \%$ and $74.7 \%$ of the respondents belong to women and religious group, respectively. This suggests a high social status because of their membership and high involvement in their various groups. Sarania (2015) and Adeleke-Bello and Ashimolowo (2015) affirmed that membership of women in social groups is helpful for their empowerment, eradication of poverty and accessibility to information.

Table 8: Membership of a social group (social status)

\begin{tabular}{lcc}
\hline Groups & Yes $\%$ & Total \\
\hline Agricultural & 15.7 & 84.3 \\
Cooperative & 8.4 & 91.6 \\
Credit & 1.9 & 98.1 \\
Fadama & 14.9 & 88.9 \\
Women groups & 48.7 & 51.3 \\
Religious groups & 74.7 & 25.3 \\
\hline
\end{tabular}

Source: Field survey, 2016

\section{Political status}

Findings shows that majority of the respondents had low political status as shown in Table 9. This is expected as most of the respondents were not holding leadership position in their groups. Tanwir and Safdar (2013) and Kivoi (2014) stated that holding of political leadership positions will avail rural women the rights to freedom of expression, freedom of association and ability to decide more on community issues.

Table 9: Position as an executive (political status)

\begin{tabular}{lc}
\hline Position & $\%$ \\
\hline 1. President & 0.6 \\
2. Vice President & 0.4 \\
3. Secretary & 5.7 \\
4. Treasurer & 5.7
\end{tabular}

Source: Field survey, 2016 
Creative Commons User License: CC BY-NC-ND

Abstracted by: EBSCOhost, Electronic Journals Service (EJS),

Google Scholar, Journal Seek, Scientific Commons,

Food and Agricultural Organization (FAO), CABI and Scopus

http://eoi.citefactor.org/10.11226/v23i1
Journal of Agricultural Extension

Vol. 23 (1) January, 2019

ISSN(e): 24086851; ISSN(Print); 1119944X

http://journal.aesonnigeria.org

http://www.ajol.info/index.php/iae

Email: editorinchief@aesonnigeria.org

\section{Time-use status}

Table 10 reveals that greater proportions of the respondents were satisfied with time used for activities. This could be because those activities have become routine and they do not have any choice in doing otherwise. Rural women with high time use status would have control over their time which will enable them to participate in activities of their choice, hence, involvement in productive and economic activities which is expected to improve their capabilities as corroborated by Erdil, Eruygur and Kasnakoghu (2006).

The empowerment status of respondents being low on table 11 could be attributed to the fact that most women are less empowered in terms of decision-making and politics in most rural communities of the nation as resources needed to boost their empowerment status were denied.

Table 10: Time use status

\begin{tabular}{lccr}
\hline Activities & Very Satisfied (\%) & $\begin{array}{l}\text { Total } \\
\text { Satisfied } \\
(\%)\end{array}$ & Not Satisfied (\%) \\
\hline Sleeping/resting & 13.0 & 73.0 & 13.8 \\
Personal care & 19.2 & 78.2 & 2.7 \\
Farm work & 9.6 & 74.3 & 16.1 \\
Shopping & 5.4 & 60.5 & 34.1 \\
Watching T.V & 4.2 & 40.6 & 55.2 \\
Listening to Radio & 11.1 & 51.7 & 37.2 \\
Visit health centres when & 12.6 & 77.0 & 10.3 \\
necessary & & & \\
Taking of children/elderly & 21.5 & 68.6 & 10.0 \\
Domestic chores & 19.5 & 67.4 & 13.0 \\
Visiting friends/neighbours & 51.0 & 48.7 & 5.4 \\
Personal work/job & 11.5 & 72.0 & 16.5 \\
\hline
\end{tabular}

Source: Field survey, 2016 
Creative Commons User License: CC BY-NC-ND

Abstracted by: EBSCOhost, Electronic Journals Service (EJS),

Google Scholar, Journal Seek, Scientific Commons,

Food and Agricultural Organization (FAO), CABI and Scopus

http://eoi.citefactor.org/10.11226/v23i1
Journal of Agricultural Extension

Vol. 23 (1) January, 2019

ISSN(e): 24086851; ISSN(Print); 1119944X

http://journal.aesonnigeria.org

http://www.ajol.info/index.php/iae

Email: editorinchief@aesonnigeria.org

Table 11: Categorisation of respondents into high and low empowerment status

\begin{tabular}{llll}
\hline Empowerment status & $\%$ & Scores & Mean \\
\hline Low & 51.0 & $98.0-155.5$ & 155.5 \\
High & 49.0 & $155.6-196.0$ & \\
\hline
\end{tabular}

\section{Difference in the Empowerment Status}

Table 12 shows that there is a significant difference $(F=47.615 ; p<0.05)$ in the empowerment status of respondents across the States. This implies that the empowerment status of respondents was significantly different across the States surveyed. The Post Hoc multiple tests reveals that the difference between the empowerment status of respondents in Oyo and Edo, Oyo and Benue; Oyo and Sokoto; Edo and Benue, and Benue and Sokoto were significant as shown in table 12. The difference between the empowerment status of respondents in Edo and Sokoto States was not significant. The non-significant difference existing in respondents' empowerment status in Edo and Sokoto States could be due to the fact that though they differ in culture and location, they still have almost the same assets and resources that could contribute to their empowerment status.

Table 12: Difference in the empowerment status

\begin{tabular}{|c|c|c|c|c|}
\hline Variable & $\begin{array}{l}\text { Sum } \\
\text { squares }\end{array}$ & of $\mathrm{Df}$ & $\begin{array}{l}\text { Mean } \\
\text { square }\end{array}$ & $\mathbf{F}$ \\
\hline Between groups & 32333.816 & 3 & 10777.939 & $47.6^{*}$ \\
\hline Within groups & 58173. 632 & 257 & 226.357 & \\
\hline Total & 90507.448 & 260 & & \\
\hline
\end{tabular}

${ }^{*} P \leq 0.05$ Source: Field survey, 2016 
Creative Commons User License: CC BY-NC-ND

Abstracted by: EBSCOhost, Electronic Journals Service (EJS),

Google Scholar, Journal Seek, Scientific Commons,

Food and Agricultural Organization (FAO), CABI and Scopus

http://eoi.citefactor.org/10.11226/v23i1
Journal of Agricultural Extension

Vol. 23 (1) January, 2019

ISSN(e): 24086851; ISSN(Print); 1119944X

http://journal.aesonnigeria.org

http://www.ajol.info/index.php/iae

Email: editorinchief@aesonnigeria.org

Table 13: Post Hoc multiple test showing difference in respondents' empowerment status

\begin{tabular}{cccll}
\hline I (State) & $(\mathbf{J})$ State & Mean difference (I-J) & Standard error & Sig. value \\
\hline LSD Oyo & Edo & 11.894 & 2.507 & $0.000^{*}$ \\
& Benue & 29.694 & 2.507 & $0.000^{*}$ \\
& Sokoto & 15.676 & 2.637 & $0.000^{*}$ \\
\multirow{2}{*}{ Edo } & Benue & 17.800 & 2.747 & $0.000^{*}$ \\
& Sokoto & 3.781 & 2.865 & 0.188 \\
Benue & Sokoto & -15.675 & 2.865 & $0.000^{*}$
\end{tabular}

The mean difference is significant at the 0.05

Relationship between Socio-economic characteristics and empowerment status From Table 14, income, educational attainment, household size and years of experience had significant positive relationship with empowerment status. This implies that when rural women are educated, have better income, more household size with higher years of experience in their economic activities, they will be better empowered. This corroborates the findings of Ogato, 2013 that income and educational level of women is a strong indicator for their being empowered.

Table 14: Relationship between Socio-economic characteristics and empowerment status

\begin{tabular}{ll}
\hline Variables & $r$ \\
\hline Income & $0.403^{*}$ \\
Educational attainment & $0.478^{*}$ \\
Household size & $0.084^{*}$ \\
Years of experience & $0.235^{*}$ \\
Area of land & 0.048 \\
\hline
\end{tabular}

${ }^{*} \mathrm{P} \leq 0.05, \mathrm{r}=$ correlation coefficient

\section{Conclusion and Recommendations}

The study concluded that respondents had low decision-making status, high economic status, high social status, low political status and high time use status. Respondents had low empowerment status in the overall. Income, educational attainment and years of experience in various enterprises had positive significant relationship to the empowerment status of respondents. 
Creative Commons User License: CC BY-NC-ND

Abstracted by: EBSCOhost, Electronic Journals Service (EJS),

Google Scholar, Journal Seek, Scientific Commons,

Food and Agricultural Organization (FAO), CABI and Scopus
Journal of Agricultural Extension

Vol. 23 (1) January, 2019

ISSN(e): 24086851; ISSN(Print); 1119944X

http://journal.aesonnigeria.org

http://www.ajol.info/index.php/iae

Email: editorinchief@aesonnigeria.org

http://eoi.citefactor.org/10.11226/v23i1

Rural women should be empowered through the efforts of government agencies and NGOs by organising seminars on self-help projects and giving them voice which will help them to contribute significantly to their family and also enable them have a sustainable farm community.

\section{References}

Acharya, D.R., Bell, J.S., Simkhada, P., Teijlingen, E.R. \& Regmi, P.R. (2010). Women's Autonomy in Household Decision-making: A Demographic Study in Nepal. Journal of Reproductive Health, Vol 7, No 15.

Adeleke, A.I., Adeoye, A.S \& Odedeji, A.D. (2016). Challenges to Rural Women Economic Empowerment Programme in Agricultural Development Programme in Ogun State, Proceedings of the $21^{\text {st }}$ Annual National Conference of the Agricultural Extension Society of Nigeria (AESON) held at the University of Ibadan, Ibadan, pg. 160.

Adeleke-Bello, O.O. \& Ashimolowo, O.R. (2015). Beneficiaries' Perception of Selected Rural Women Empowerment Projects in Ogun State, Nigeria, African Journal of Agricultural Research, Vol 10, No 44, pp 4108-4116, Retrieved July 7, 2016 from http://doi.org/10.5897/AJAR2014.9363.

Ajadi, A.A., Oladele, I.O., Ikegami, K and Tsuruta, T. (2015). Rural Women's Access to Productive Resources: the Moderating Effect of Culture among Nupe and Yoruba in Nigeria. Agriculture and Food Security, Vol 4, No 26.

Akinbode, S.O and Hamzat, S.G. (2017). Women Asset Ownership and Household Poverty in Rural Nigeria, Journal of Studies in Social Sciences, Vol 16, No 1, 45-64.

Campbell, M.M., Prata, N. and Potts, M. (2012). The Impact of Freedom on Fertility Decline, Journal of Family Planning Reproductive Health Care, Vol 39, issue 1, pp 44-50, Retrieved July 17, 2016 from http://www.jfprhc.bmj.com/content/39/1/44.full

Diiro, G.M., Seymour, G.,Kassie, M., Muricho, G. and Muriithi, B.W. (2018). Women's Empowerment in Agriculture and Agricultural Productivity: Evidence from Rural Women Maize Farmer Households in Western Kenya, PLOS ONE 13 (5) : e0197995, Retrieved October 11, 2018 from https://doi.org/10.1371/journal.pone.0197995.

Doss, C.R. (2017). Women and Agricultural Productivity: Reframing the Issues, Development Policy Review, Vol 36, issue 1, pg 35-50, Retrieved October 11, 2018 from https://doi.org/10/1111/dpr.12234.

Dudafa, U.J. (2013). Record Keeping among Small Farmers in Nigeria: Problems and Prospects, International Journal of Scientific Research in Education, Vol 6, No 2, Pp 214-220, Retrieved March 13, 2016 from www. ljsre.com/Vol, 6_2_Dudafa.pdf.

Elferink, M and Schierhorn, F (2016). Global Demand for Food is Rising. Can we meet it? Harvard Business Review, Retrieved November 1, 2018 from www.hbr.org/2016/04/global-demand-for-food-is-rising-can-we-meet-it/.

Erdil, E., Eruygur, O. and Kasnakoghu, Z. (2006). Time Use in Rural Areas: A Case Study in Turkey, Economic Research Center, ERC Working Papers in Economics 06/02, Retrieved June 1, 2017 from http://www.erc.metu.edu.tr/menu/series06/0602.pdf. 
Creative Commons User License: CC BY-NC-ND

Abstracted by: EBSCOhost, Electronic Journals Service (EJS),

Google Scholar, Journal Seek, Scientific Commons,

Food and Agricultural Organization (FAO), CABI and Scopus
Journal of Agricultural Extension

Vol. 23 (1) January, 2019

ISSN(e): 24086851; ISSN(Print); 1119944X

http://journal.aesonnigeria.org

http://www.ajol.info/index.php/iae

Email: editorinchief@aesonnigeria.org

Fabiyi, E.F. \& Akande, K.E. (2015). Economic Empowerment for Rural Women in Nigeria: Poverty Alleviation through Agriculture, Journal of Agricultural Science, Vol 7, No 9, pp 236-241.

Fletscher, D and Kenney, L. (2011). Rural women's access to financial services: credit, savings and insurance, an ESA working paper No 11-07 presented to the State of Food and Agriculture Organisation (FAO)

lyela, A. \& Ikwuakam, O.T. (2015). Poverty Coping Strategies of Rural Women dwellers of Batagarawa Local Government Area of Katsina State, Nigeria, Mediterranean Journal of Social Sciences, Vol 6, No 6, pp 296-306.

Karim, R., Lindberg, L and Wamala, S. (2017). Men's Perception of Women's Participation in Developmental Initiatives in Rural Bangladesh, American Journal of Men's Health, Retrieved September 26, 2018 from https://doi.org/10.1177/155988317735314.

Kivoi, D.L. (2014). Factors Impeding Political Participation and Representation of Women in Kenya, Humanities and Social Sciences, Vol 2, No 6, pp 173-181, Retrieved July 7, 2016 from www. doi.org/10.11648/j.hss.20140206.15.

Narayan, D. (2005). Measuring Empowerment, Cross Disciplinary Perspectives, Washington D.C: World Bank, Retrieved October 17, 2014 from https://openknowledge.worldbank.org/handle/10986/7441.

Ogato, G.S. (2013). The Quest for Gender Equality and Women's Empowerment in Least Developed Countries: Policy and Strategy Implications for Achieving Millennium Development Goals in Ethiopia, International Journal of Sociology and Anthropology, Vol 5 (9), pp 358-392, www. doi.org/10.5897/IJSA2013.0454.

Ogunsumi, L.O., Adeyeye, V.A and Fato, F.B. (2017). Comparative Assessment of Women Involvement in Farming and Family Life in Rural Parts of Nigeria, Journal of Agricultural Science, Vol 9, No 9, Retrieved September 28, 2018 from https://http.doi.org/10.5539/jas.v9n9p201.

Ojo, C.O, Bila, Y \& Iheanacho. (2015). Women's Accessibility to Resources of Agricultural Productivity in Borno State, Nigeria. Journal of Economics and Sustainable Development, Vol 6, No 5, Retrieved July 4, 2016 from http://www.iiste.org/journals/index.php/JEDS/article/viewfile/20705/21627.

Sadeghi, H, Arezoumandan, R \& Nejati, B. (2015). The Role of Women in Rural Development: A Cooperative Development Approach, A Case Study on Iran, Journal of Agricultural Extension and Rural Development, Vol 7, No 9, pp 272-282, Retrieved January 25, 2018 from http://www.academicjournals.org/journal/JAERD/article-full-textpdf/F4F02FD55987.

Sarania, R. (2015). Impact of Self-Help Groups on Economic Empowerment of Women in Assam, International Research Journal of Interdisciplinary and Multidisciplinary Studies (IRJIMS), Vol 1, issue 1, pg 148-159, Retrieved July 7, 2016 from http://www.irjims.com.

Tanwir, M \& Safdar, T. (2013). The Rural Women's Constraints to Participation in Rural Organisation. Journal of International Women's Studies, Vol 14, issue 3, pp 210229, Retrieved July 4, 2016 from http//ve.bridgew.edu/jiws/vol14/iss3/15. 
Creative Commons User License: CC BY-NC-ND

Abstracted by: EBSCOhost, Electronic Journals Service (EJS),

Google Scholar, Journal Seek, Scientific Commons,

Food and Agricultural Organization (FAO), CABI and Scopus

http://eoi.citefactor.org/10.11226/v23i1
Journal of Agricultural Extension

Vol. 23 (1) January, 2019

ISSN(e): 24086851; ISSN(Print); 1119944X

http://journal.aesonnigeria.org

http://www.ajol.info/index.php/jae

Email: editorinchief@aesonnigeria.org

Tefera, T. (2013). Land Ownership - the Path towards Rural Women Empowerment: a case from Southern Ethiopia, International Journal of Sociology and Anthropology, Vol 5, No 8.

Yusuf, T.M, Okunmadewa, F.Y, Adenegan, K.O \& Oyekale, A.S. (2010). Productivity of Women Farmers in the Derived Savannah Zone of Nigeria: Panacea to Food Crisis. Journal of Research in National Development, Vol 8, No 1, Retrieved March 11, 2016fromhttp://www.transcampus.org/JORINDV8Jun2010/JournalsV8No1Jun2010 50. 